\title{
Sosyal Medya Reklamları Etkili Midir? Algının ve Tutumun Satın Alma Niyetine Etkisinde Ünlü Desteğinin Aracı Rolü : Y Kuşağı Üzerinde Bir Araştırma (Are Social Media Ads Effective? The Mediating Role of Celebrity Endorsement in the Effect of Perception and Attitude on the Purchase Intention: A Study on the Y Generation)
}

\author{
Hasan AKSOY iD a Ayşe GÜR iD b Emel CELEP iD c \\ a Gaziantep Üniversitesi, İ̈BF, Uluslararası Ticaret ve Lojistik Bölümü, Gaziantep, Türkiye. haksoy@gantep.edu.tr \\ b Gaziantep Üniversitesi, İ̈BF, Uluslararası Ticaret ve Lojistik Bölümü, Gaziantep, Türkiye. aysegur27@gmail.com \\ c Selçuk Üniversitesi, İ̈BF, İşletme Bölümü, Konya, Türkiye. ecelep@selcuk.edu.tr
}

\begin{tabular}{|c|c|}
\hline MAKALE BİLGİSI & ÖZET \\
\hline Anahtar Kelimeler: & Amaç - Sosyal medya ağlarının, firmalar için yeni bir rekabet alanına ve tanıtım mecrasına dönüşmesi sosyal \\
\hline Sosyal Medya Reklamları & medya reklamlarının günümüzde etkili bir tutundurma faaliyeti haline gelmesini sağlamıştır. Firmalar \\
\hline Ünlü Desteği & çekici, alanında uzman ve güvenilir ünlülerle iş birliği ile markalarının tanıtımını yaparak tüketicilere \\
\hline Tüketici Tutumu & ulaşmaktadır. Bu çalışmanın temel amacı, Y kuşağındaki tüketicilerin sosyal medya reklamlarına yönelik \\
\hline & algılarının ve tutumlarının satın alma niyeti üzerindeki etkisinde ünlü desteğinin aracı etkisini incelemek \\
\hline Gönderilme Tarihi 24 & ve $Y$ kuşağı tüketicilerin sosyal medya reklamlarına yönelik algısı ve tutumu ile satın alma niyeti arasındaki \\
\hline Mayıs 2021 & ilişkiyi belirlemektir. \\
\hline Revizyon Tarihi 26 & m - Bu doğrultuda çalışmada, Y kuşağındaki tüketicilerin sosyal medya reklam algılarının ve \\
\hline Temmuz 2021 & tutumlarının, tüketicinin satın alma niyeti üzerindeki etkisinde ünlü desteğinin aracı etkisini incelemek \\
\hline Kabul Tarihi 30 Temmuz & üzere bir model geliştirilmiştir. Y kuşağında bulunan 405 bireye yüz yüze ve çevrimiçi olarak anket \\
\hline 2021 & uygulanmıştır. Elde edilen veriler AMOS programı aracılığıyla test edilmiştir. \\
\hline \multirow{4}{*}{$\begin{array}{l}\text { Makale Kategorisi: } \\
\text { Araştırma Makalesi }\end{array}$} & $\begin{array}{l}\text { Bulgular - Araştırma sonuçlarına göre, sosyal medya reklamlarına yönelik tüketici algısının ve tüketici } \\
\text { tutumunun satın alma niveti üzerinde etkili olduğu, aynı zamanda ünlü desteğinin sosval medva }\end{array}$ \\
\hline & $\begin{array}{l}\text { tutumunun satın alma nıyetı uzerınde etkili oldugu, aynı zamanda unlu desteğının sosyal medya } \\
\text { reklamlarına yönelik tüketici algısının ve tüketici tutumunun satın alma niyeti üzerindeki etkisinde arac1 }\end{array}$ \\
\hline & $\begin{array}{l}\text { etkiye sahip olduğu sonucuna varılmıştır. Ayrıca sosyal medya reklamlarındaki ünlü desteğinin tüketici } \\
\text { satın alma niyeti üzerinde olumlu etkileri olduğu sonucuna varılmıştır. }\end{array}$ \\
\hline & $\begin{array}{l}\text { Tartışma - Firma sahiplerinin markaları ile benzer kimliğe ve imaj özelliklerine sahip ünlülerle çalışması, } \\
\text { tüketicilerin satın alma niyetine önemli katkıda bulunmaktadır. Tüketicilerin sosyal medya reklamları algısı } \\
\text { ve tutumunun satın alma niyetine etkisinin kısmi olarak ünlü desteği ile sağlandığı sonucu da, sosyal } \\
\text { medya reklamlarında ünlü desteğinin önemini vurgulamaktadır. }\end{array}$ \\
\hline
\end{tabular}

\begin{tabular}{l} 
ARTICLE INFO \\
\hline Keywords: \\
Social Media Ads \\
Celebrity Endorsement \\
Consumer Behavior
\end{tabular}

Received 24 May 2021 Revised 26 July 2021 Accepted 30 July 2021

Article Classification: Research Article

\section{ABSTRACT}

Purpose - The transformation of social media networks into a new competition area and promotion area for companies has made social media advertisements an effective promotion activity today. Companies reach consumers by promoting their brands in cooperation with attractive, expert and reliable celebrities. The main purpose is to examine the celebrity endorsement in the effect of perceptions and attitude towards social media advertisements of $Y$ generation consumers and to determine the relationship between the perception and attitude of generation $Y$ consumers towards social media ads and their purchasing intention.

Design/methodology/approach - In this study, a model has been developed to examine the mediating effect of celebrity endorsement on the influence of social media advertising perceptions and attitudes of millennial consumers on purchase intention. Face-to-face and online surveys were applied to 405 people in generation Y. The data obtained was tested through the AMOS program.

Findings - According to the results of the research, it was concluded that while the perception of the consumer towards social media advertisements and the attitude of the consumer affect the purchase intention, the celebrity support has an intermediary effect. In addition, it was concluded that celebrity support in social media ads has positive effects on the purchasing intention of the consumer.

Discussion - Company owners work with celebrities who have similar identities and image features with their brands, making a significant contribution to the purchasing intention of consumers. The result that the effect of the perception and attitude of consumers on social media ads on the purchase intention is partially provided by celebrity support, emphasizes the importance of celebrity support in social media ads. 


\section{Giriş}

Günümüz dünyasında teknolojide yaşanan gelişmelere paralel olarak internet kullanımı her yıl giderek artmaktadır. İnternet kullanımının artmasıyla sosyal medya mecralarında ve bu mecraların kullanımında ciddi bir artış görülmüştür. Türkiye'de 2020 We are social araştırmasına göre 54 milyon sosyal medya kullanıcısı bulunduğu belirtilmekle birlikte, 25-34 yaş arası en önemli sosyal medya kullanıcı grubu olarak dikkat çekmektedir. Türkiye'deki sosyal medya tıklanma oranları ele alındığında; Facebook aylık 423.700.000 kez tıklanmakta olup, her ziyaretin süresi ise ortalama 8 dakika 52 sn.'dir; Instagram ise aylık 169.800 .000 kez tıklanırken, her ziyaretin süresi 8 dakika 46 saniye olarak gerçekleşmiştir. Son olarak ise Twitter aylık 193.900.000 kez tıklanırken, ziyaret süresi 10 dakika 57 saniye olarak gerçekleşmiştir (wearesocial.com). We Are Social Ocak 2021 raporundaki verilere göre ise Türkiye nüfusunun yaklaşık \%71'inin (60 milyon kişi) aktif sosyal medya kullanıcısı olduğu (We Are Social, 2021); bir önceki yıla göre de aktif sosyal medya kullanıcı sayısında yaklaşık \%11,1'lik artış olduğu belirtilmiştir. Sosyal medya araçlarının kullanımının artmasıyla geleneksel medya önemini yitirmiş olup geleneksel medyaya göre daha hızlı ve daha düşük maliyetli olan sosyal medya mecraları önem kazanmıştır. Bu gelişmelere bağlı olarak tüketicilere ulaşmanın en etkili ve kısa yolu sosyal medya araçları olarak görülmektedir. İşletmeler, sosyal medyada takipçi sayısı yüksek, popüler, alanında uzman, çekici ve güvenilir bulunan ünlülerle iş birliği yaparak marka veya ürünlerini tüketiciye tanitmaktadır. Dolayısıyla sosyal medya hesabı bulunan veya sosyal medyayı kullanan tüketiciler ve potansiyel müşterilerin bu mecralarda yürütülen marka ve ürünlerle ilgili tanıtım çalışmalarına veya tutundurma kampanyalarına maruz kaldığı söylenebilir.

Bu bağlamda çalışmanın temel amacı, Y kuşağındaki tüketicilerin sosyal medya reklamlarına yönelik algılarının ve tutumlarının satın alma niyeti üzerindeki etkisinde ünlü desteğinin aracı etkisini incelemektir. Ayrıca bu çalışmanın bir diğer amacı, Y kuşağı tüketicilerin sosyal medya reklamlarına yönelik algısı ve tutumu ile satın alma niyeti arasındaki ilişkiyi belirlemektir.

Bu bağlamda çalışmada cevap aranan sorular şu şekilde sıralanmaktadır:

-Sosyal medya reklamlarına yönelik tüketici algısı, sosyal medya reklamlarındaki ünlü desteği üzerinde etkili midir?

-Sosyal medya reklamlarına yönelik tüketici algısının satın alma niyeti üzerinde bir etkisi var mıdır?

-Sosyal medya reklamlarındaki ünlü desteğinin, satın alma niyeti üzerinde bir etkisi var mıdır?

-Sosyal medya reklamlarına yönelik tüketici tutumunun sosyal medya reklamlarındaki ünlü desteği üzerinde bir etkisi var midır?

-Sosyal medya reklamlarına yönelik tüketici tutumunun satın alma niyeti üzerinde etkisi var mıdır?

Sosyal medya reklamları işletmelerin tüketiciye ulaşabilmesinin etkili yollarından biridir. Beğendiği ünlüleri veya markaları sosyal medya aracılı̆̆ıyla takip eden kullanıcılar, sosyal medyada çeşitli şekillerde reklamlara maruz kalmaktadır. Tüketicilerin söz konusu reklamlardan nasıl etkilendiğini inceleyen bu araştırma, reklam şirketleri ve firmalar için tutundurma faaliyetlerinin yürütülmesinde ve kampanyaların geliştirilmesinde birçok faydalı bilgi sağlayacaktır. Zaman veya mekân kısıtlaması olmadan sosyal medya aracılığıyla mal ve hizmetlerle ilgili reklamlar tüketicilere sunulabilmektedir. Bu sebeple sosyal medyada aktif şekilde yer alan firmalar, tüketicilerin dikkatini daha fazla çekebilmektedir. Ayrıca sosyal medya reklamlarında ünlülerin kullanılması etkili bir reklam stratejisi olmakla birlikte bu stratejinin etkinliğinin incelenmesi hem tüketicilerin sosyal medya reklamlarına yönelik algılarını hem de sektörü anlamak adına önemli bir rol oynamaktadır.

\section{Kavramsal Çerçeve}

Tüketiciler farklı istek ve ihtiyaçlarının karşılanması noktasında gelişen üretim teknikleri ve teknolojinin bir sonucu olarak birçok seçenekle karşı karşıya bulunmaktadır. Mal ve hizmet çeşitliliğinin bir sonucu olarak seçim yapma ve karar verme sürecinin çok daha karmaşık bir hale gelmesi tüketici satın alma davranışının, satın alma davranışını etkileyen faktörlerin ve davranışın ortaya çıkması sürecinin daha yakından incelenmesini gerekli kılmaktadır. Tüketici satın alma davranışının ortaya çıkmasında bireylerin maruz kaldıkları çeşitli uyaranlar olması, bu uyaranların tüketicilerin dikkatini çekme ve algı eşiklerini geçme durumunun farklı olması, tüketicilerin farklı uyaranlara farklı biçimlerde tepki göstermelerine yol açmakta; 


\section{H. Aksoy - A. Gür - E. Celep 13/3 (2021) 2340-2355}

bu durum ise farklı algı ve tutumların ortaya çıkmasına neden olmaktadır. Bir ihtiyacın giderilmesi amacıyla bireyin belirli mal ve hizmete yönelmesi ile şekillenen satın alma niyetinin, özellikle işletmelerin tutundurma çalışmaları ya da tutundurma alt karması bileşenlerini kullanma biçiminden oldukça fazla etkilendiği söylenebilir. Bu bileşenler arasında uygulama alanının genişliği ve tüketicilere ulaşma noktasındaki gücü ile özellikle reklamların alg1 ve tutumların oluşmasında diğer bileşenlere göre çok daha etkili olduğu görülmektedir. Buna ek olarak reklamların içeriği, sunulma biçimi, reklam ile gönderilen tutundurma mesajları da satın alma niyetinin şekillenmesinde önemli sayılan konular arasındadır. Aynı zamanda tüketicilerin marka, mal veya hizmetlerle ilgili değerlendirme yapma aşamasında işletmeler tarafından reklamlarda ünlü kullanımı, olumlu yönde uyaran genellemesi yapılmasına neden olabilmektedir. Bu noktada tüketiciler alanında uzman, popüler, güvenilir veya duyulara seslenen bir takım özellikler taşıyan ünlülerin kullanıldığı reklamlar aracılı̆̆ıla marka ve ürün ile ilgili de aynı olumlu duygulara sahip olabilmektedir. Bu bağlamda, kişilere ulaşma noktasındaki gücü ile sosyal medya reklamlarının ve kişileri etkileyebilme gücü ile sosyal medya reklamlarında ünlü desteğinin, satın alma niyetinin oluşmasında büyük rolü olan algı ve tutumların şekillenmesinde önemli etkenler olarak ele alınması önemli kabul edilmektedir. Çalışmanın kavramsal çerçevesinin oluşmasında önem arz eden ve araştırmanın esasını oluşturan temel kavramlar Tablo 1'de açıklandığ 1 gibidir:

Tablo 1: Araştırma Değişkenleri

\begin{tabular}{|l|l|l|}
\hline Değişkenler & Tanım & Kaynak \\
\hline Algı & $\begin{array}{l}\text { Deneyimler, tutumlar, inançlar, gereksinimler, } \\
\text { uyarıcı faktörler, durumsal bileşenler ve etraftaki } \\
\text { olaylar temelinde duyu organları aracılı̆̆ı ile elde } \\
\text { edilen duyulara yüklenen anlam. }\end{array}$ & Gülmez ve Dörtyol, 2013 \\
\hline Tutum & $\begin{array}{l}\text { Bir kişinin bazı nesne veya fikirlere karşı olumlu } \\
\text { veya olumsuz değerlendirmeleri, duyguları ve } \\
\text { eylem eğilimlerini sürdürmesidir. }\end{array}$ & Tsang vd., 2004 \\
\hline Ünlü Desteği & $\begin{array}{l}\text { Kamuoyu tarafından tanınan bir kişinin bir } \\
\text { reklamda görünerek belirli amaçlar doğrultusunda } \\
\text { bu tanınmayı tüketici yararına kullanmasıdır. }\end{array}$ & McCracken, 1989 \\
\hline Satın Alma Niyeti & $\begin{array}{l}\text { Tüketicinin bir mal, hizmet veya markadan belirli } \\
\text { bir zaman aralığında, belirli miktarda satın almayı } \\
\text { planlamasıdır. }\end{array}$ & Gökalan, 2009 \\
\hline
\end{tabular}

\subsection{Tüketici Algısı Kavramı ve Reklama Yönelik Tüketici Algısı}

Algı, bireyin deneyimler, tutumlar, inançlar, gereksinimler, uyarıcı faktörler, durumsal bileşenler ve etraftaki olaylar temelinde duyu organları aracılığı ile elde ettiği duyulara yüklemiş olduğu anlam şeklinde ifade edilmektedir (Gülmez ve Dörtyol, 2013). Tüketicilerin sosyal medya reklamlarına yönelik algıları üzerinde sosyal medya reklamlarında kullanılan görsel ve işitsel araçlar, dil ve üslup, mesajın içeriği gibi faktörler oldukça büyük bir etkiye sahiptir (Akkaya, 2013: 107). İlgili literatür incelendiğinde sosyal medya reklamlarında tüketici algısının genel olarak beş grupta ele alındığı görülmektedir:

Bilgi Sağlama: Reklamların bilgi sağlaması, reklamların güncellenmiş, zamanında ve kolay erişilebilir bilgiler sunma kabiliyetidir (Ünal vd., 2011: 365).

Eğlence Sunma: Tüketicilerin komik ve eğlenceli algıladıkları reklamlar onların ilgisini çeker ve bağlılık yaratırken, eğlence hizmetleri de müşteri sadakatini arttırıp müşteri için bir değer sağlayabilmektedir. Eğlenceli bir reklamın alıcı tarafından olumlu olarak algılanması söz konusudur (Haghirian vd., 2005: 4).

Güvenilir Olma: Reklamlar, ürünlerle ilgili bilgileri ilk elden taşıdıkları için tüketiciler tarafından reklamların güvenilir olarak algılanması markaya da güven duyulmasında etkili olmaktadır (Çinkay, 2017: 69). 


\section{H. Aksoy - A. Gür - E. Celep 13/3 (2021) 2340-2355}

Ekonomiye Katkı Sağlama: Ekonominin reklamlardan nasıl etkilendiğine ilişkin iki farklı bakış açısı bulunmaktadır. Bunlardan ilki, reklamların kararsız olan tüketicinin alternatifler arasından belirli bir markayı seçmesini sağladığıdır. Diğer yaklaşım ise reklamların tüketicinin algısını mekân, tanınırlık ve fiyat açısından etkilemekte olduğudur (Meral, 2006: 395).

Değer Yozlaşması: İnsanlar sosyal medya reklamlarının inandıkları değer sistemiyle uyuşmadığını düşündüklerinde sosyal medya reklamlarına karşı olumsuz bir eğilim göstermektedirler (Wang ve Sun, 2010: 102).

\subsection{Tutum Kavramı ve Reklama Yönelik Tüketici Tutumu}

Pazarlama bilimi ve özellikle tüketici davranışları alanında önemli bir kavram olan tutum için Fishbein (1967), "insanoğlunun öğrenilmiş bir yatkınlığı" ifadesini kullanmıştır. Kotler ise bir kişinin bazı nesne veya fikirlere karşı olumlu veya olumsuz değerlendirmeleri, duyguları ve eylem eğilimlerini sürdürmesini tutum olarak ifade etmiştir (Tsang vd., 2004: 66). Reklamlara yönelik tutum ise kişilerin reklamlara göstermiş oldukları pozitif veya negatif tepkiler olup, reklama yönelik tutum ve reklama yönelik genel tutum olmak üzere iki tutum kavramı literatürde yer almaktadır. Lutz vd. (1983), reklama yönelik tutumu, kişinin belirli bir süre boyunca belirli bir reklam uyarıcısına maruz bırakılması sonucunda göstermiş̧ olduğu olumlu veya olumsuz tepki olarak tanımlamıştır. Reklamlara yönelik genel tutumu ise, kişinin olumlu veya olumsuz tepkilerini içeren ve süreklilik gösteren öğrenilmiş eğilimleri olarak tanımlamaktadır (Akyüz, 2010: 215).

\section{3. Ünlü Desteği Kavramı ve Reklamda Ünlï Desteği}

Firmalar mal ve hizmetleri için rekabet avantajı sağlayacak farklı stratejilerden yararlanmaktadır. Ünlü desteği, bu stratejiler arasında yaygın olarak kullanılanlardan biridir (Erdoğan, 1999: 291). Kamuoyu tarafından tanınan ve bir reklamda görünerek belirli amaçlar doğrultusunda bu tanınmayı tüketici yararına kullanan herhangi bir kişi, "ünlü onaylayan" olarak tanımlanmaktadır (McCracken, 1989: 310). Bir diğer ifadeyle, reklamlarda rol alıp ürünleri onaylayan ünlülere "Celebrity Endorsemer", yani "Ünlü Onaylayıcı" denilmektedir. Reklamlarda kullanılacak ünlülerin seçimi, doğru pazarlama stratejileriyle belirlenmesi ve hedef kitleyi etkilemesi önemlidir. Ohanian (1990)'ın geliştirdiği üç faktörlü kaynak güvenilirliği ölçeği bu çalışmanın temelini oluşturmaktadır. Kaynak güvenilirliği; bir iletişimcinin, alıcının bir mesajı kabul etmesinde etkili olan olumlu özelliklerini niteleyen bir ifade olup (Ohanian, 1990: 41) konuyla ilgili güvenilirlik, çekicilik ve uzmanlık faktörleri bu çalışmada kullanılmıştır.

\subsection{Satın Alma Niyeti}

Bir tüketicinin bir mal, hizmet veya markadan belirli bir zaman aralığında, belirli miktarda satın almayı planlaması satın alma niyetini tanımlamaktadır (Gökalan, 2009: 68). Satın alma niyeti, bir kişinin alışveriş durumunda iyi bir şey satın alma olasılığını (mal varlığının mevcudiyeti, maddi imkânlar vb.) gösteren varsayımlardan oluşan bir yapı olarak tanımlanabilir ve satın alma karar sürecinde oldukça önemlidir (Barnes vd., 2007: 76). Bir tüketicinin belirli bir mal veya hizmete ihtiyacı olduğu anda o mal veya hizmeti satın almayı tercih etmesi ve o mal veya hizmete karşı tutumu satın alma niyetini açıklamaktadır. Satın alma niyeti başka bir ifadeye göre, tüketicinin bir ürünü değerlendirdikten ve satın almaya değer olduğunu anladıktan sonra bir kez daha ürünü satın alacağı anlamına gelmektedir (Madahi ve Sukati, 2012: 153).

\section{Hipotezler ve Araştırma Modeli}

\subsection{Sosyal Medya Reklamlarına Yönelik Tüketici Algısı}

Sosyal medya reklamlarının bilgi verici nitelikte olması, eğlence sunması, güvenilir olması ve ekonomiye katkı sağlamasının, tüketici tutumu ve satın alma davranışı üzerinde pozitif etkileri olduğu birçok araştırmacı tarafından onaylanmıştır (Ducoffe, 1996; Azeem ve Haq, 2012; Wang ve Sun, 2010; Ünal vd., 2011; Uçar, 2013; Yücel ve Kızkapan, 2016; Aksoy ve Gür, 2018; Zengin, 2018). Buna rağmen Wang vd. (2009), çalışmasında reklamların eğlence sunmasının ve güvenilir olmasının tüketici tutumunu etkilemediği sonucuna ulaşmıştır. Sosyal medya reklamlarına yönelik algı faktörlerinden birisi de değer yozlaşması faktörüdür. Yapılan araştırmalar değer yozlaşması faktörünün tüketici tutumu ve satın alma davranışı üzerinde negatif etkiye sahip olduğunu göstermektedir (Ducoffe, 1996; Wang ve Sun, 2010; Ünal vd., 2011; Azeem ve Haq, 2012). Bu çalışmalardan yola çıkarak bu araştırmada test edilen hipotezlerden birisi de şu şekilde belirlenmiştir: 


\section{H. Aksoy - A. Gür - E. Celep 13/3 (2021) 2340-2355}

H1a: Sosyal medya reklamlarına yönelik tüketici algısının sosyal medya reklamlarındaki ünlü desteği üzerinde pozitif etkisi vardır.

\subsection{Sosyal Medya Reklamlarna Yönelik Tutum}

Akkaya (2013) yapmış olduğu çalışmada, sosyal medya reklamlarına yönelik tüketici tutumunun, tüketici davranışı ve tüketici satın alma niyeti üzerinde pozitif yönlü bir etkiye sahip olduğunu belirtmiştir. İnce ve Bozyiğit (2018) yaptıkları çalışmada, sosyal medya reklamlarına karşı tüketici tutumunun satın alma öncesi ve satın alma sonrası tüketici davranışlarını çeşitli yönlerden etkilediği sonucuna ulaşmışlardır. Bu değişkenler ile ilgili yapılan çalışmaların sonuçlarının değerlendirilmesi neticesinde araştırmanın ikinci hipotezi aşağıdaki gibi formüle edilmiştir.

$\mathbf{H}_{2 a:}$ Sosyal medya reklamlarına yönelik tüketici tutumunun sosyal medya reklamlarındaki ünlü desteği üzerinde pozitif etkisi vardır.

\subsection{Sosyal Medya Reklamlarnda Ünlü Desteği}

Araştırmacılar reklamlarda ünlü kullanımını ve sosyal medya reklamlarının tüketici davranışı üzerindeki etkilerini çeşitli yönlerden incelemiştir. Sosyal medya reklamlarında ünlülerin kullanılması tüketicilerin sosyal medya reklamlarını güvenilir algılamasını sağlamaktadır (Solak, 2016). Sosyal medya reklamlarındaki ünlülerin tüketici algısı üzerinde pozitif etkileri bulunmaktadır (Çinkay, 2017). Birçok araştırmacıya göre sosyal medya reklamlarında kullanılan ünlülerin çekici, uzman ve güvenilir olmaları tüketicilerin tutumlarını ve satın alma niyetlerini pozitif yönde etkilemektedir (Çardakl1, 2008; Ilicic ve Webster, 2011; Kirezli, 2015; Ha ve Lam, 2017; Zengin, 2018). Buna rağmen Ohanian (1991) yaptığı çalışmada reklamda kullanılan ünlünün çekici ve güvenilir olmasının tüketici üzerinde pek etkisi olmadığı, ancak uzman ünlülerin bulunduğu reklamların tüketicilerin satın alma davranışı üzerinde oldukça etkili olduğu sonucuna ulaşmıştır. Bu çalışmalardan yola çıkarak bu araştırmada aşağıdaki hipotez test edilmiştir:

H3: Sosyal medya reklamlarındaki ünlü desteğinin tüketicilerin satın alma niyeti üzerinde pozitif etkisi vardır.

\subsection{Sosyal Medya Reklamlarına Yönelik Tüketici Algısı ve Tüketici Tutumunun Satın Alma Niyetine Etkisinde Ünlü Desteği}

Wang vd. (2013) yaptığı çalışmada ünlü desteğinin satın alma niyeti üzerinde pozitif etkisi olduğu sonucuna ulaşmıştır. Nasir vd. (2016), ünlü desteğinin Pakistanlı tüketicilerin satın alma niyeti üzerindeki etkisini incelemiş ve ünlü desteğinin tüketicilerin satın alma niyeti üzerinde anlamlı ve pozitif etkisi olduğu sonucuna ulaşmıştır. Ayrıca yapılan çalışmada marka performansının, ünlü desteğinin satın alma niyeti üzerindeki etkisinde aracı etkisi olduğu sonucuna ulaşılmıştır. Nguyen (2021) yaptığı çalışmada, bir akıllı telefon reklamında kullanılan ünlü desteğinin Vietnam'da yaşayan tüketicilerin satın alma niyeti üzerindeki etkisini incelemiş olup ünlülerin fiziksel çekiciliğinin, güvenilirliğinin, popülerliğinin ve uzmanlığının satın alma niyeti üzerinde olumlu etkileri olduğunu ortaya koymuştur. Bu değişkenler ile ilgili yapılan çalışmaların sonuçlarının değerlendirilmesi neticesinde araştırmanın diğer hipotezleri aşağıdaki gibi formüle edilmiştir:

Hib: Sosyal medya reklamlarındaki ünlü desteği, sosyal medya reklamlarına yönelik tüketici algısının tüketicilerin satın alma niyeti üzerindeki etkisinde aracllık etkisine sahiptir.

$\mathbf{H}_{2 b:}$ Sosyal medya reklamlarındaki ünlü desteği, sosyal medya reklamlarına yönelik tüketici tutumunun tüketicilerin satın alma niyeti üzerindeki etkisinde aracılık etkisine sahiptir.

Bu sonuçlar doğrultusunda araştırmanın modeli Şekil 1'deki gibi oluşturulmuştur: 


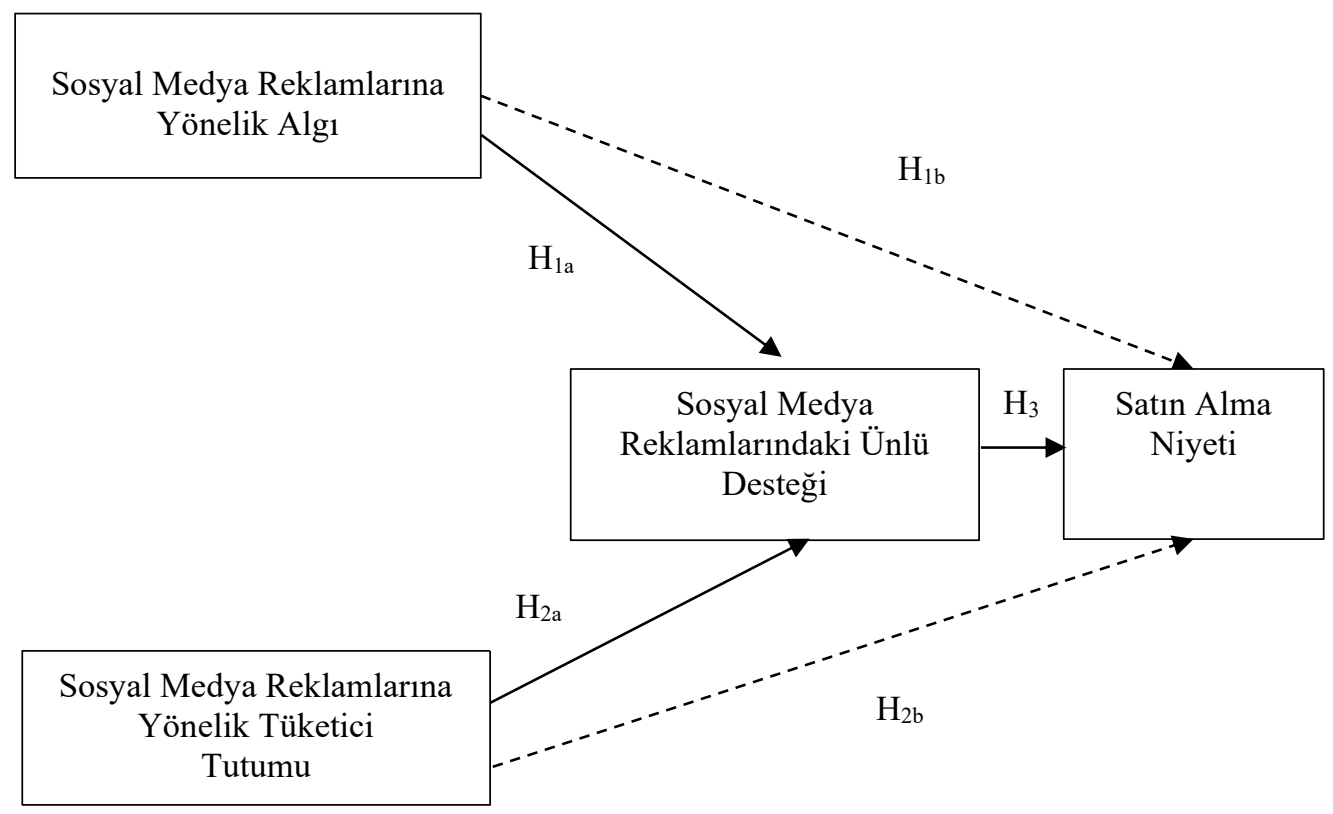

Şekil 1: Araştırma Modeli-Ünlü Desteğinin Aracı Rolü

\section{Metodoloji}

\subsection{Evren ve Örneklemin Belirlenmesi}

Araştırmanın ana kütlesi olarak Y Kuşağındaki tüketiciler seçilmiştir. Y Kuşağı 1980-1999 yılları arasında doğanları kapsamaktadır (Smyrl, 2011; Kuş, 2016; Kuyucu, 2017). Y kuşağı teknolojiyle erken tanışan ve çok fazla teknolojiye maruz kalmış olup bilişsel, duygusal ve sosyal açıdan avantaj ve dezavantaja sahip olan kuşaktır. Dijital gelişmelerle büyüyen ilk kuşak olan Y kuşağı üyelerinin üçte ikisi beş yaşından önce bilgisayarla tanışmışlardır. Bu kuşakta yer alan bireyler, başkalarıyla etkileşime girme, eğlence gibi amaçlarla teknolojiyi kullanmakta olup duygusal anlamda da teknolojiye çok fazla güvenmektedirler. Bu kuşağın internet ve sosyal medyayı sıklıkla kullanan bireylerden oluşması ve bu mecrada yapılan tutundurma faaliyetlerinin bu kuşakta bulunan tüketicilerin tutum ve niyetleri üzerinde etkili olabileceği düşüncesinden yola çıkarak ana kütle belirlenmiştir.

Araştırmanın evrenini Gaziantep Üniversitesi kampüsünde okuyan 40.000 lisans öğrencisi oluşturmaktadır. Yapılan hesaplamalar sonucunda evreni temsil gücüne sahip örneklemin 381 kişi olduğu tespit edilmiştir. Araştırmacılar tarafından bu sayının üzerinde bir gruba anketin uygulanması daha güvenilir olacağı düşünüldüğü için örneklem sayısı 650 olarak belirlenmiştir.

\subsection{Veri Toplama Araci veya Veri Seti}

Araştırmada kolayda örnekleme yöntemiyle, Y Kuşağında bulunan 650 katılımcıya yüz yüze ve çevrimiçi anket uygulaması yapılmıştır. Uygulanan bu anketler arasından eksik bırakılmış olanlar çıkarıldıktan ve toplanan anket verileri temizlendikten sonra yanıt oranı $\% 62$ 'yi karşılayan, toplam 405 katılımcının verisi SPSS ve AMOS programları kullanılarak analiz edilmiştir (Sekaran, 1992). Katılımcılar tarafından eksiksiz olarak tamamlanan ve değerlendirmeye alınan 405 anket'in 189 tanesi çevrimiçi; 216 tanesi yüzyüze olarak uygulanan anketlerden oluşmuştur. Birincil veri toplama yöntemi ile verilerin frekans dağılımlarına bakılmış faktör, güvenilirlik ve korelasyon analizleri yapılmıştır. Son olarak Yapısal Eşitlik Modeli yöntemi kullanılarak ünlü desteğine ait aracılık etkisi test edilmiştir. Veri toplama aşamasına geçilmeden önce Gaziantep Üniversitesi Sosyal ve Beşeri Bilimler Etik Kurulundan gerekli onay alınmıştır (Kurul Adı: Gaziantep Üniversitesi Sosyal ve Beşeri Bilimler Etik Kurulu, Toplantı No: 07, Toplantı Tarihi: 27.04.2021, Toplantı Saati: 11:00). 


\subsection{Anket Formunun Hazırlanması}

Araştırma, dört değişkenli bir alan araştırması olarak tasarlanmış olup veri toplamak için anket yönteminden faydalanılmıştır. Anket formu demografik ölçek dışında 4 bölüm ve 40 ifadeden oluşmaktadır. Demografik ölçekte kişinin yaşı, cinsiyeti, medeni durumu, eğitim durumu ve aylık geliri ile ilgili sorular sorulmuştur. İlk bölümde kişinin en fazla kullandığı sosyal medya mecrası açık uçlu bir şekilde sorulmuştur. İkinci bölümde sosyal medya reklamlarındaki ünlü desteğine yönelik ifadeler yer almaktadır. Üçüncü bölümde sosyal medya reklamlarına yönelik tüketici algısını ve satın alma niyetini ölçmeye yönelik ifadeler bulunmaktadır. Son bölümde ise reklamlara yönelik tutumu ölçmeye yönelik ifadeler yer almaktadır. Bu ifadeler 5'li likert ölçeğine göre hazırlanmıştır. Tüm değişkenler “Kesinlikle Katılmıyorum” (1)'dan “Kesinlikle Katıllyorum” (5)'a doğru sıralanan 5’li Likert ölçeği kullanılarak ölçülmüştür.

Sosyal medya mecralarının günümüzde sıklıkla kullanılmasıyla birlikte sosyal medya reklamlarında ünlü desteği de firmalar tarafından fazla tercih edilen bir yöntem olmuştur. Literatür incelendiğinde sosyal medya reklamları ve ünlü kişilerin reklamlarda rol almasının tüketici davranışları üzerindeki etkisini çeşitli yönlerden inceleyen çalışmaların bulunduğu görülmektedir. Bu çalışma sırasında kapsamlı bir literatür taraması yapılmış ve çeşitli ölçeklerden yararlanılmıştır. Araştırmanın kavramsal çerçevesi kapsamında reklamlardaki ünlü desteği konusunda Wang vd. (2017)'nin çalışmasında kullandığ1 reklamlardaki ünlü desteği ile ilgili ölçekten yararlanılmıştır. Tüketici algısı ile ilgili olarak Pollay ve Mittal (1993), Wang vd. (2009) ve Uçar (2013)'ın çalışmalarında kullandığı tüketici algısı ölçeğinden faydalanılmıştır. Satın alma niyeti konusunda Mikalef vd. (2013) çalışmalarında kullanmış olduğu satın alma niyeti ölçeğinden ve tutum konusunda Wolin vd. (2002)'nin çalışmalarında kullanmış olduğu tutum ölçeğinden faydalanılmıştır. Literatürdeki çeşitli çalışmalar incelenerek bir anket formu oluşturulmuş ve birincil kaynaktan veriler toplanmıştır.

Anket sorularının İngilizce 'den Türkçe 'ye çevrilmesi için her iki dili de bilen uzmanlardan yardım alınmıştır. Pazarlama alanında çalışan üç akademisyen tarafından çevirisi yapılan sorularda dil bilgisinde problem olan ve anlaşılamayan sorular incelenerek çalışmanın amaçna uygun olarak son hali verilmiştir. Daha sonra ana kütleyi temsil eden ve rastgele seçilen 10 yüksek lisans öğrencisi anket sorularının anlamlılığını değerlendirmiştir. Soruları yanıtlayan öğrenciler, soruları anlamakta zorluk çekmediklerini ifade etmiştir.

\section{Araştırma Verilerinin Analizi ve Bulgular}

\section{1.Örneklem Özellikleri}

Araştırmaya katılanların demografik bilgileri incelendiğinde, katılımcıların \%62'sini kadınların \%38'ini erkeklerin oluşturduğu görülmektedir. Katılımcıların \%95,1'i bekâr bireylerden oluşurken \%4,7'si evli bireylerden oluşmaktadır. Bu durum, ana kütlenin Y Kuşağındaki tüketicilerden seçilmesiyle açıklanabilir. Ayrıca anketi cevaplayanların \%90,6'sı eğitim durumuna üniversite, \%4,9'u lise, \%3,2'si yüksek lisans ve \%1,3'ü ilkokul cevabını vermiştir. Katılımcıların büyük çoğunluğunun yani \%63'ünün aylık gelirinin 0-1000 $\mathrm{TL}$ aralığında olduğu, 5000TL ve üzeri aylık gelire sahip katılımcıların oranının $\% 2,2$ olduğu görülmektedir.

Tablo 2. Katılımcıların Demografik Bilgileri

\begin{tabular}{|l|c|c|}
\hline & Frekans & Yüzde \% \\
\hline Yaș & 405 & 100 \\
\hline 19-38 & & \\
\hline Cinsiyet & 251 & 62 \\
Kadın & 154 & 38 \\
Erkek & & \\
\hline Medeni Durum & 19 & 4,7 \\
Evli & 385 & 95,1 \\
Bekâr & 1 & 0,2 \\
Cevaplanmayan & & \\
\hline
\end{tabular}




\begin{tabular}{|l|c|c|}
\hline Ĕgitim Durumu & 5 & \\
İlköğretim & 20 & 1,3 \\
Lise & 367 & 4,9 \\
Üniversite & 13 & 90,6 \\
Yüksek lisans & 0 & 3,2 \\
Doktora & & 0 \\
\hline Aylık Gelir & 255 & 63 \\
0-1000TL & 65 & 16 \\
1001-2000TL & 37 & 9,2 \\
2001-3000TL & 10 & 2,5 \\
3001-4000TL & 9 & 2,2 \\
4001-5000TL & 9 & 2,2 \\
5001 ve üzeri & 20 & 4,9 \\
Cevaplanmayan & $\mathbf{4 0 5}$ & $\mathbf{1 0 0}$ \\
\hline Toplam & & \\
\hline
\end{tabular}

Ankete katılanlara en fazla kullandıkları sosyal medya mecrası açık uçlu şekilde sorulmuştur. Katılımcıların $\% 3,2$ 'si Facebook, \%65,5'i Instagram, \%0,2'si Pinterest, \%9,6's1 Twitter, \%10,1'i Whatsapp, \%8,2'si Youtube kullandığını belirtmiştir. Katılımcıların \%3,2'si ise bu soruya yanıt vermemiştir. Tablo 3 incelendiğinde katılımcıların en fazla kullandığı sosyal medya mecrasının Instagram olduğu görülmektedir.

Tablo 3. Ankete Katılanların En Çok Kullandığı Sosyal Medya Mecraları

\begin{tabular}{|l|c|c|}
\hline Sosyal Medya Mecrası & Frekans & Yüzde \\
\hline Facebook & 13 & 3,2 \\
\hline Instagram & 265 & 65,5 \\
\hline Pinterest & 1 & 0,2 \\
\hline Twitter & 39 & 9,6 \\
\hline Whatsapp & 41 & 10,1 \\
\hline Youtube & 33 & 8,2 \\
\hline Cevaplanmayan & 13 & 3,2 \\
\hline Toplam & $\mathbf{4 0 5}$ & $\mathbf{1 0 0}$ \\
\hline
\end{tabular}

\subsection{Güvenilirlik ve Faktör Analizleri}

Bir ölçeğin veya bir testin ölçmeyi amaçladığı şeyi istikrarlı ve tutarlı bir şekilde ölçme derecesi güvenilirliği oluşturmaktadır. Güvenilirlik ölçülürken en sık kullanılan yöntem Cronbach Alpha olarak da bilinen alfa katsayısıdır (Altunışık vd., 2010: 122-124). Cronbach alfa katsayısının 0.70'ten büyük olduğu durumlar, verilerin içsel tutarlılığının yüksek olduğunu göstermektedir (Gupta vd., 1997: 514). Tablo 4 incelendiğinde verilerin Cronbach Alpha katsayılarının 0.716 ile 0.898 arasında olduğu görülmektedir. Bu sonuçlara göre; ölçekte yer alan her bir soru grubunun ve ölçeğin tümünün yüksek güvenilirlikte olduğu söylenebilir.

Tablo 4. Ölçeklere İlişkin Cronbach Alpha, KMO ve Barlett's Test Katsayıları

\begin{tabular}{|l|l|l|l|}
\hline ÖLÇEK & Cronbach Alpha & KMO & Barlett's Test \\
\hline Tüketici Algisı & .864 & .852 & 3812.871 \\
\hline Tüketici Tutumu & .849 & .714 & 540.133 \\
\hline Ünlü Desteği & .849 & .868 & 1692.373 \\
\hline Satın Alma Niyeti & .816 & .770 & 750.113 \\
\hline
\end{tabular}

Faktör analizi, birbiriyle ilişkili çok sayıdaki değişkeni daha az sayıda, daha anlamlı, kolay anlaşılabilir ve birbirinden bağımsız faktörler haline getirmektedir. Faktör analizi, oldukça sık kullanılan çok değişkenli bir istatistik tekniğidir (Bozkır vd., 2012: 47). Faktör analizinin uygunluğu Kaiser-Meyer-Olkin (KMO) testi ile anlaşılmaktadır. KMO oranının yüksek olması veri setinin faktör analizi yapmak için uygun olduğunu göstermektedir. Araştırmacıların genelde yeterli olduğunu düşündüğü KMO değeri $0.7^{\prime}$ dir (Altunışık vd., 2010: 266). Uygulanan anket formunun yapı geçerliliği faktör analizi Varimax Döndürme (Rotation) metodu 
uygulanarak belirlenmiştir. Tüm ölçeklerin KMO değerleri 0.689 ve 0.868 arasında oldukça iyi değerlere sahiptir.

\subsection{Korelasyon Analizi}

Korelasyon analizi, bir araştırmada bulunan bir değişkenin diğer bir veya birden fazla değişkenle arasında ilişki olup olmadığını test etmek amacıyla kullanılan istatistiksel bir yöntemdir. Değişkenler arasındaki ilişki negatif yönlü güçlü bir ilişkiyse korelasyon katsayısı -1'e yakın bir değer alırken, pozitif yönlü güçlü bir ilişkinin olduğu bir durumda +1'e yakın değer almaktadır (Ural ve Kılıç, 2005: 219).

Tablo 5. Korelasyon Analizi ve Iraksak Geçerlilik

\begin{tabular}{|c|c|c|c|c|}
\hline & (1) & (2) & (3) & (4) \\
\hline 1. Tüketici Algısı & (.793) & & & \\
\hline 2.Tüketici Tutumu & $.575^{* *}$ & (.812) & & \\
\hline 3. Ünlü Desteği & $.504^{* *}$ & $.371^{* *}$ & (.685) & \\
\hline 4. Satın Alma Niyeti & $.537^{* *}$ & $.562^{* *}$ & $.376^{* *}$ & $(.721)$ \\
\hline
\end{tabular}

**: 0.01 düzeyinde anlamlı

Tablo 5'te çalışmaya ait verilerin Korelasyon Analizi yer almaktadır. Değişkenler arasındaki ilişkiyi gösteren Korelasyon Analizi sonuçları incelendiğinde, tüm değişkenler arasında anlamlı ilişkiler olduğu görülmektedir. Bu ilişkiler; tüketici algısı ile tüketici tutumu (.575), ünlü desteği (.504) ve benzer şekilde satın alma niyeti (.484) ile aynı yönlü olarak tablodan izlenmektedir. Tüketici tutumu ile ünlü desteği (.371) ve satın alma niyeti (.562) arasındaki ilişkinin aynı yönlü olduğu görülmektedir. Son olarak, ünlü desteği ile satın alma niyeti (.376) arasında da aynı yönlü bir ilişkinin olduğu görülmektedir.

Tablo 5'te araştırmaya ait Korelasyon Analiziyle birlikte Iraksak Geçerlilik sonuçları yer almaktadır. Iraksak geçerlilik, değişkenlere ait ifadelerin ilişkili oldukları faktörlerle, ait olmadıkları faktörlerden daha fazla ilişkili olmasıdır (Yaşlığlu, 2017: 82). Modele ilişkin ıraksak geçerliliğin tespit edilmesinde ise bir değişkene ait AVE değerinin karekökünün bu değişkene ait korelasyon değerlerinden büyük olması yeterlidir (Aksoy, 2019: 588). Tablo 5'te ifade edilen sonuçların her değişken için ıraksak geçerliliği sağladığı görülmektedir.

Tablo 6. Değişkenlerin Ortalama Açıklanan Varyans Değerleri

\begin{tabular}{|c|c|c|c|c|}
\hline & İfadeler & Faktör & AVE & C.R. \\
\hline \multirow{14}{*}{ 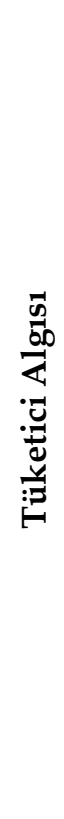 } & Sosyal medya reklamları ürün bilgisi için kaynaktır. & .779 & \multirow{14}{*}{0.63} & \multirow{14}{*}{0.96} \\
\hline & Sosyal medya reklamları ürünle alakalı bilgiler sunar. & .786 & & \\
\hline & Sosyal medya reklamları güncel bilgiler verir. & .702 & & \\
\hline & Sosyal medya reklamları eğlencelidir. & .916 & & \\
\hline & Sosyal medya reklamları zevklidir. & .908 & & \\
\hline & Sosyal medya reklamları memnuniyet vericidir. & .809 & & \\
\hline & Sosyal medya reklamları ilgi çekicidir. & .743 & & \\
\hline & Sosyal medya reklamları inandırıcıdır. & .848 & & \\
\hline & Sosyal medya reklamları güvenilirdir. & .869 & & \\
\hline & Sosyal medya reklamları akla yatkındır. & .799 & & \\
\hline & $\begin{array}{l}\text { Toplum yararına olan ürünlerle ilgili sosyal medya reklamları } \\
\text { daha iyi sonuçlar verir. }\end{array}$ & .683 & & \\
\hline & $\begin{array}{l}\text { Sosyal medya reklamcılığı modern ekonomide önemli bir rol } \\
\text { oynar. }\end{array}$ & .724 & & \\
\hline & $\begin{array}{l}\text { Sosyal medya reklamları toplumumuzda istenmeyen değerleri } \\
\text { teşvik eder. }\end{array}$ & .739 & & \\
\hline & Sosyal medya reklamları gençliğin değerlerini deforme eder. & .872 & & \\
\hline
\end{tabular}




\begin{tabular}{|c|c|c|c|c|}
\hline & $\begin{array}{l}\text { Sosyal medya reklamlarındaki bazı ürünlerin toplumumuz } \\
\text { üzerinde negatif etkileri vardır. }\end{array}$ & .700 & & \\
\hline \multirow{3}{*}{ 穿焉 } & Sosyal medya reklamları bana göre çok iyidir. & .827 & \multirow{3}{*}{0.66} & \multirow{3}{*}{0.85} \\
\hline & Sosyal medya reklamlarını çok beğenirim. & .877 & & \\
\hline & Sosyal medya reklamları bana göre çok gereklidir. & .729 & & \\
\hline \multirow{7}{*}{ 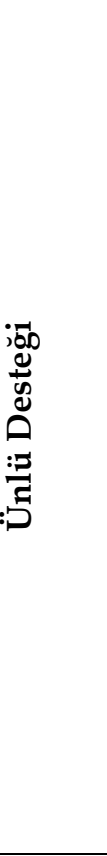 } & $\begin{array}{l}\text { Fiziksel olarak çekici (güzel, zarif, klas) olan ünlülerin olduğu } \\
\text { sosyal medya reklamlarını izlemeyi tercih ederim. }\end{array}$ & .701 & \multirow{7}{*}{0,50} & \multirow{7}{*}{0.88} \\
\hline & $\begin{array}{l}\text { Çekiciliğin sosyal medya reklamında oynayan bir ünlü için } \\
\text { önemli bir özellik olduğunu düşünüyorum. }\end{array}$ & .678 & & \\
\hline & $\begin{array}{l}\text { Fiziksel açıdan çekici bir ünlünün oynadığı sosyal medya } \\
\text { reklamının, ünlü bir markaya karşı olan satın alma niyetimi } \\
\text { etkilediğini hissediyorum. }\end{array}$ & .690 & & \\
\hline & $\begin{array}{l}\text { Alanında uzman olan bir ünlünün oynadığı sosyal medya } \\
\text { reklamlarına daha fazla dikkat ediyorum. }\end{array}$ & .708 & & \\
\hline & $\begin{array}{l}\text { Sosyal medya reklamlarında uzman bir ünlü tarafından } \\
\text { desteklenen bir markanın daha güvenilir olduğunu } \\
\text { düşünüyorum. }\end{array}$ & .763 & & \\
\hline & $\begin{array}{l}\text { Güvenilir bir ünlünün olduğu sosyal medya reklamları, o } \\
\text { reklamı ve desteklenen ürünü hatırlamamı sağladığını } \\
\text { hissediyorum. }\end{array}$ & .664 & & \\
\hline & $\begin{array}{l}\text { Sosyal medya reklamlarında güvenilir bir ünlü tarafından } \\
\text { desteklenen bir markanın daha saygın ve cazip olduğunu } \\
\text { düşünüyorum. }\end{array}$ & .749 & & \\
\hline \multirow{3}{*}{ 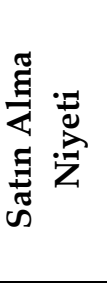 } & $\begin{array}{l}\text { Sosyal medya sitelerinden gördüğüm bir ürünü biraz } \\
\text { düşündükten sonra satın alırım. }\end{array}$ & .721 & \multirow{3}{*}{0.52} & \multirow{3}{*}{0.77} \\
\hline & $\begin{array}{l}\text { Sosyal medya aracılığıyla araştırdığım bazı mal veya hizmetleri } \\
\text { satın alırım. }\end{array}$ & .745 & & \\
\hline & $\begin{array}{l}\text { Son zamanlarda birçok ürünü, sosyal medya sitelerinden } \\
\text { edindiğim bilgiler ışı̆̆ında satın aldım. }\end{array}$ & .701 & & \\
\hline
\end{tabular}

Tablo 6'da araştırmanın değişkenlerine ait Ortalama Varyansları (Average Variances Extracted) ve Bileşik Güvenilirlikleri (C.R.: Composite Reliabilities) yer almaktadır. Araştırmanın yakınsak geçerliliği için; CR (birleşik güvenilirlik) değerinin 0.60'ın üzerinde olması ve AVE (açıklanan varyans değerleri) değerinin 0.50'nin üzerinde olması kabul edilebilir değerlerdir (Fornell ve Larcker, 1981). Tablo 6 incelendiğinde çalışmadaki tüm değişkenlerin yakınsak geçerliliği sağladığı görülmektedir.

\subsection{Hipotez Testleri}

Ünlü desteğinin, sosyal medya reklamlarına yönelik tüketici algısı ve tüketici tutumunun satın alma niyeti üzerindeki etkisinde aracı değişken rolünü test etmek için Baron ve Kenny (1986) tarafından önerilen üç aşamalı regresyon analizi yöntemi kullanılmıştır. Bu amaçla, ünlü desteğinin etkisini görebilmek için iki ayrı yapısal eşitlik modeli oluşturulmuş ve test edilmiştir. Araştırma hipotezlerinden ilk üçünü test etmek için Yapısal Eşitlik Modeli (YEM) kullanılmıştır. Tablo 7' de çalışmada yer alan YEM analizi sonuçlarına ait bilgiler yer almaktadir.

Tablo 7: Model YEM Sonuçları

\begin{tabular}{llllllll}
\hline $\begin{array}{l}\text { Yordanan } \\
\text { Değişken }\end{array}$ & $\begin{array}{l}\text { Yordayan } \\
\text { Değişken }\end{array}$ & $\begin{array}{l}\text { Std. Fäktör } \\
\text { Yükleri }\end{array}$ & S.E. & C.R. & P & Hipotez & Sonuç \\
\hline Ünlü Desteği & Alg1 & .428 & .070 & 8.326 & $* * *$ & $\mathrm{H}_{1 a}$ & Kabul \\
Ünlü Desteği & Tutum & .133 & .043 & 2.589 & 0.10 & $\mathrm{H}_{2 a}$ & Kabul \\
Niyet & Ünlü & .103 & .050 & 2.278 & .023 & $\mathrm{H}_{3}$ & Kabul \\
\hline
\end{tabular}

$\mathrm{X}^{2} / \mathrm{df}=1.911, \mathrm{CFI}=0.939, \mathrm{GFI}=0.884, \mathrm{RMSEA}=0.047, \mathrm{NFI}=0.082$ 


\section{H. Aksoy - A. Gür - E. Celep 13/3 (2021) 2340-2355}

Araştırma modeline ait uyum iyiliği sonuçlarına göre; $x^{2} / \mathrm{df}$ değeri 1.911'dir, yani model mükemmel bir uyum göstermektedir (Tabachnick ve Fidell, 2001; Kline, 2015; Sümer, 2000). AGFI, 0,862 değerinde olup kabul edilebilir uyuma sahiptir (Steiger, 1990; Schumacker ve Lomax, 2004; Hooper vd., 2008; Sümer, 2000). CFI, 0.939 değer ile iyi uyum göstermektedir (Bentler, 1990; Sümer, 2000). GFI değeri 0.884 olup kabul edilebilir uyuma sahiptir (Steiger, 1990; Schumacker ve Lomax, 2004; Hooper vd., 2008; Sümer, 2000). RMSEA, 0.047 değeri ile mükemmel uyum (Weston ve Gore, 2006; Bentler: 1990; Kline, 2015), NFI ise 0.882 ile kabul edilebilir uyum göstermektedir (Schumacker ve Lomax, 2004; Bentler, 1990; Sümer, 2000). Bu veriler doğrultusunda modele ait uyum iyiliği sonuçlarına bakıldığında istenilen değerler arasında uyum iyiliği sonucuna ulaşıldığı görülmektedir. Modele ait YEM analiz sonuçları incelendiğinde sosyal medya reklamlarına yönelik tüketici algısının sosyal medya reklamlarındaki ünlü desteğinin üzerinde pozitif etkisinin olduğu sonucuna varılmaktadır. Ayrıca "sosyal medya reklamlarına yönelik tüketici tutumunun sosyal medya reklamlarındaki ünlü desteği üzerinde pozitif etkisi vardır" hipotezinin de desteklendiği görülmektedir. Sosyal medya reklamlarındaki ünlü desteğinin tüketicilerin satın alma niyeti üzerinde pozitif etkisi bulunmaktadır. Dolayısıyla $\mathrm{H}_{1 a}$, $\mathrm{H}_{2 a}$ ve $\mathrm{H}_{3}$ kabul edilmiştir.

\subsection{Aracı Etkisi}

Aracı etkisinin hipotezlerinin önemini test etmek için \%95 güven aralığı seviyesinde Bootstrap yönteminde örneklem 10.000 değerinde arttırılmış ve yöntem olarak Bias-corrected confidance intervals seçilmiştir (Cheung ve Lau, 2008). Tablo 8'de alt düzey ve üst düzey sınırlar arasında sıfır değerinin yer alamaması, çalışmadaki değişkenler arasındaki ilişkinin bootstrap yöntemine göre değerlendirilebileceğini göstermektedir.

Tablo 8: Aracı Etkisi Sonuçları

\begin{tabular}{|c|c|c|c|c|c|}
\hline Aracı İlişki & Etki & Alt Düzey & Üst Düzey & Etki & Aracilık \\
\hline \multirow{3}{*}{ Alg1 $\rightarrow$ Ünlü $\rightarrow$ Niyet } & Doğrudan Etki & 159 & 374 & $.265^{* *}$ & \multirow{3}{*}{ Kismi } \\
\hline & Dolaylı Etki & ,007 & ,098 & $.044^{* *}$ & \\
\hline & Toplam Etki & ,207 & 416 & $.309^{* * *}$ & \\
\hline \multirow{3}{*}{ Tutum $\rightarrow$ Ünlü $\rightarrow$ Niyet } & Doğrudan Etki & ,283 & 468 & $.377^{* *}$ & \multirow{3}{*}{ Kısmi } \\
\hline & Dolaylı Etki & 010 & 042 & $.014^{* *}$ & \\
\hline & Toplam Etki & ,292 & , 484 & $.391^{* * *}$ & \\
\hline
\end{tabular}

**: 0.01 düzeyinde anlamlı, ${ }^{* * *}: 0.001$ düzeyinde anlamlı

Modele ait YEM analiz sonuçlarına bakıldığında, ünlü desteğinin aracı etkisinin incelendiği bu çalışmanın analizi sonucunda sosyal medya reklamlarına yönelik tüketici algısının satın alma niyeti üzerindeki etkisinde ünlü desteğinin aracı etkisinin olduğu sonucuna varılmıştır. Hıb: Sosyal medya reklamlarındaki ünlü desteği, sosyal medya reklamlarına yönelik tüketici algısının tüketicilerin satın alma niyeti üzerindeki etkisinde aracılık etkisine sahiptir" görüşünün ileri sürüldüğü $\mathrm{H}_{1 b}$ hipotezi kabul edilmiştir $(\mathrm{p}=020)$. Tüketici tutumunun satın alma niyeti üzerindeki etkisinde ünlü desteğinin aracı etkisinin de bulunduğu sonucuna varılmıştır. Tablo 8'de sunulan sonuçlar da, ünlü desteğinin kısmen, tüketici algısının satın alma niyeti üzerine etkisine aracılık ettiğini göstermektedir. $\mathbf{H}_{2 b}$ : Sosyal medya reklamlarındaki ünlü desteği, sosyal medya reklamlarına yönelik tüketici tutumunun tüketicilerin satın alma niyeti üzerindeki etkisinde aracılık etkisine sahiptir" görüşünün ileri sürüldüğü $\mathrm{H}_{2 b}$ hipotezi kabul edilmiştir $(\mathrm{p}=035)$. Ünlü desteğinin arabuluculuğunda algının satın alma niyeti üzerindeki doğrudan etkisi 0.265 , dolaylı etki ise 0.044 olup; algının satın alma niyeti üzerindeki toplam etkisinin \%14'ünü oluşturmaktadır. Sonuç olarak algının satın alma niyeti üzerindeki etkisinin kısmi olarak ünlü desteği ile sağlandı̆̆ı söylenebilir. Aynı şekilde, ünlü desteğinin arabuluculuğunda tutumun satın alma niyeti üzerindeki doğrudan etkisi 0.377 , dolaylı etki ise 0.014 olup; algının satın alma niyeti üzerindeki toplam etkisinin \%4'ünü oluşturmaktadır. Sonuç olarak tutumun satın alma niyeti üzerindeki etkisinin kısmi olarak ünlü desteği ile sağlandığı söylenebilir.

\section{Sonuç ve Öneriler}

Tüketicilerin mal ve hizmet satın alma sürecinde birçok farklı alternatif arasından seçim yapma şansına sahip olmaları her bir işletmeyi kendi mal ve hizmetinin tercih edilebilir olması noktasında farklı stratejiler uygulamaya zorunlu hale getirmektedir. Bu strateji ve uygulamalar arasında ürün ve markalar ile ilgili 


\section{H. Aksoy - A. Gür - E. Celep 13/3 (2021) 2340-2355}

farkındalığın sağlanması noktasında farklı tutundurma çalışmalarının giderek daha fazla önem kazandığı görülmektedir. Geçmiş dönemlere kıyasla son yıllarda tutundurma mecralarının da çeşitlilik göstermesinde internetin gelişimi etkili olmakla birlikte, buna bağlı olarak ortaya çıan sosyal medya platformlarının geniş bir kullanıcı kitlesine sahip olması önemli bir gelişme olarak görülmektedir. Özellikle sosyal medya platformlarının günün her saatinde kullanıcılar tarafından ziyaret edilen mecralar olması, bu alanda yapılan tutundurma çalışmalarının çok daha geniş bir kitleye ulaşabilmesinde etkili olmaktadır. Pazarlamanın temelini oluşturan pazarlama karması elemanlarından tutundurma bileşeni için oldukça önemli yeri olan reklamlar aracılığıyla firmalar mal ve hizmetlerini tüketicilere tanıtmaktadır. Geleneksel medya araçlarından $\mathrm{TV}$, radyo, gazete ve dergilerde yer alan reklamların yanı sıra, günümüzde gelişen teknolojiye bağlı olarak kişisel bilgisayarların, akıllı telefonların ve tabletlerin sürekli kullanılır hale gelmesi ve buna paralel olarak internet kullanımının da artmasıyla insan hayatına dahil olan sosyal medya mecraları da reklamların yer aldığı alanlara dönüşmüştür. Sosyal medya, insanların fotoğraf, video, yazı, fikir, karikatür, haber ve dedikodu gibi içerikleri paylaşmak için kullandığı online (çevrimiçi) kaynaklardır. Geleneksel medya araçlarının yanı sıra sosyal medya araçları da firmalar için bir rekabet ve pazarlama alanına dönüşmüştür. Bilginin hızla yayıldığı ve geleneksel medyaya göre daha pratik ve düşük maliyetli bir alan olan sosyal medya, firmaların yeni reklam mecrası durumuna gelmiştir. Sosyal medya, birçok kullanıcı tarafından anında erişilebilir olması sebebiyle firmalar açısından oldukça avantajı kabul edilebilir. Pazarlama iletişimi açısından bakıldığında, firmaların mal ve hizmetleri için rekabet avantajı sağlayacak stratejiler geliştirmesi önemlidir. Bu pazarlama stratejilerinin bir parçası olarak "ünlü desteği" yaygın olarak kullanılmakta olup ünlü kişilerin yer aldığı reklamlar izleyenler tarafından daha kolay hatırlanmaktadır. Bu sebeple firmalar ve reklam şirketleri tarafından markayla uyumlu, çekici, uzman ve güvenilir ünlüler reklamlarda sıkça kullanılmaktadır.

Bu çalışmada, Y kuşağındaki tüketicilerin sosyal medya reklamlarına yönelik algıları ve tutumları ile satın alma niyeti arasındaki ilişki ve bu ilişki üzerinde ünlü desteğinin aracı rolü incelenmiştir. Yapılan korelasyon ve yapısal eşitlik analizleri sonucunda sosyal medya reklamlarına yönelik tüketici algısının ünlü desteği üzerinde pozitif etkisi olduğu sonucuna varılmaktadır. Hıa: Sosyal medya reklamlarına yönelik tüketici algısının sosyal medya reklamlarındaki ünlü desteği üzerinde pozitif etkisi vardır" hipotezinin kabul edilmesi literatürde bu alanda yapılmış olan çalışmalardan elde edilen bulgularla benzerlik göstermektedir (Çağliyan vd., 2016; Ünal vd., 2011; Wang vd., 2009; Ducoffe, 1996; Aksoy ve Gür, 2018; Uçar, 2013).

Çalışmanın analiz sonuçlarına göre, tüketici tutumunun sosyal medya reklamlarındaki ünlü desteği üzerinde etkili olduğu görülmektedir. Hza: Sosyal medya reklamlarına yönelik tüketici tutumunun sosyal medya reklamlarındaki ünlü desteği üzerinde pozitif etkisi vardır" hipotezi kabul edilmiştir. Bu sonuç literatürde bu alanda yapılmış olan çalışmalardan elde edilen bulgularla benzerlik göstermektedir (Yücel ve Kızkapan, 2016; Ha ve Lam, 2017; Ünal vd., 2011).

Sosyal medya reklamlarındaki ünlü desteğinin satın alma niyeti üzerindeki etkisini inceleyen birçok çalışma yapılmıştır. Bu konuda yapılan birçok çalışmada ünlü desteğinin satın alma niyeti üzerinde etkili olduğu sonucuna varılmıştır (Ha ve Lam, 2017; Çinkay, 2017; Ilicic ve Webster, 2011; Kirezli, 2015; Solak, 2016; Ohanian, 1991). Araştırma modeline ait hipotezlerin test edilmesine ilişkin yapılan YEM (Yapısal Eşitlik Modeli) analiz sonuçları literatürde bu alanda yapılmış olan çalışmalardan elde edilen bulgularla paralel sonuçlar vermiştir ve sosyal medya reklamlarındaki ünlü desteğinin tüketicinin satın alma niyeti üzerinde etkili olduğu sonucuna ulaşılmıştır. $\mathbf{H}_{3}$ : Sosyal medya reklamlarındaki ünlü desteğinin tüketicilerin satın alma niyeti üzerinde pozitif etkisi vardır" hipotezi de kabul edilmiştir.

Sosyal medya reklamlarındaki ünlü desteğinin farklı değişkenler arasındaki ilişkide aracı etkisi birçok farklı çalışmada ele alınmıştır (Bergkvist vd. 2015; Febrian ve Fadly, 2021). Önceki çalışmalarda, marka ederi ve marka güvenilirliği arasındaki (Spry vd., 2011) sosyal ilişkiler ve sosyal medya arasındaki ilişkide ünlü desteğinin aracı etkisi üzerine çalışılmıştır. Önceki çalışmalar sosyal medya reklamlarında tutum ve algının satın alma niyeti üzerindeki etkisini araştırırken (Ducoffe, 1996; Azeem ve Haq, 2012, Aksoy ve Gür, 2018) bu değişkenlerin arasındaki ilişkide ünlü desteğinin aracı etkisiyle ilgili çalışmalar yetersiz kalmıştır. Bu çalışma, tüketicilerin sosyal medya reklamları algısı ve tutumunun satın alma niyeti üzerindeki etkisinde ünlü desteğinin aracı rolünü belirleyerek literatürdeki bu eksikliği gidermeyi amaçlamaktadır. Bu etkiyi ölçmek amacıyla geliştirilen hipotezler olan; "Hıb: Sosyal medya reklamlarındaki ünlü desteği, sosyal medya reklamlarına yönelik tüketici algısının tüketicilerin satın alma niyeti üzerindeki etkisinde aracılık etkisine sahiptir." ve "H2b: Sosyal medya reklamlarındaki ünlü desteği, sosyal medya reklamlarına yönelik tüketici 


\section{H. Aksoy - A. Gür - E. Celep 13/3 (2021) 2340-2355}

tutumunun tüketicilerin satın alma niyeti üzerindeki etkisinde aracılık etkisine sahiptir." hipotezleri kabul edilmiştir. Bu sonuç, sosyal medya reklamları ile ilgili literatüre yeni bir bakış açısı kazandırılması bakımından önem taşımaktadır.

Sonuç olarak, Y kuşağı tüketicilerin sosyal medya reklamlarından ve sosyal medya reklamlarındaki ünlü desteğinden belirli ölçülerde etkilendiği söylenebilir. Sosyal medyayı sıklıkla kullanan Y kuşağında bulunan tüketiciler sosyal medya mecralarında gördükleri reklamlardan ve ünlülerden etkilenmektedir. Ayrıca tüketiciler bir mal veya hizmeti satın almadan önce sosyal medyada araştırma yapmakta ve satın alma davranışını bu yönde şekillendirmektedir. Bunun yanında sosyal medyada fazla vakit geçiren genç kuşak bir şekilde markalar, mal veya hizmetlerle ilgili tanıtım ya da kampanyaların yürütüldüğü reklamlarla karşılaşmaktadır. İşletmeler/firmalar tarafından yapılan reklam çalışmalarında ünlü kişilerin kullanılması reklamın, ürünün ve markanın hatırlanmasını kolaylaştırma konusunda etkili olmaktadır.

\subsection{Yönetsel Öneriler}

İşletmeler, sosyal medya pazarlamasında da geleneksel pazarlama yöntemlerinde de olduğu gibi tüketicileri satın alma davranışına yönlendirmek için ünlü isimlerden yararlanmaktadır. Ünlü isimlerin son dönemlerde farklı mecralarda tutundurma faaliyetlerinde etkin bir şekilde kullanıldığı ve bu yöntemin işletmelerin müşterilerin ilgisini çekme noktasında oldukça etkili olduğu görülmektedir. Sosyal medyada da geleneksel medya kanallarında olduğu gibi toplum tarafından tanınan, satın alma davranış ve biçimleri, alışkanlıkları, tercihleri, tarzı, imajı ve diğer birçok özelliği takip edilen ve örnek alınan ünlü isimlerden faydalanılmakla birlikte; geleneksel medya kanallarından farklı olarak çeşitli marka veya ürünlerle ilgili sosyal medyanın kendi ünlülerinin de bu mecrada yaratıldığı, tanıtıldığı ve bu bağlamda daha önceden ünlü olmuş kişiler ile sosyal medyada yaratılan yeni ünlü kişilerin kullanıldığı pazarlama stratejilerinin oluşturulduğu görülmektedir. Çalışmanın sonuçlarından birisi olan ünlü desteğinin satın alma niyeti üzerindeki rolü, bu noktada firmalara, reklam ajansı sahiplerine önemli önerilerde bulunmaktadır. Çalışma sonuçlarına dayanarak, sosyal medya reklamlarında kullanılan ünlülerin satın alma niyetine olumlu bir etkisi olduğu ileri sürülebilmektedir. Firma sahipleri kendi markaları ile benzer kimliğe ve imaj özelliklerine sahip ünlülerle çalıştı̆̆ında bu durum, tüketicilerin satın alma niyetine önemli katkıda bulunmaktadır. Çalışma aynı zamanda, tüketicilerin sosyal medya reklamları algısı ve tutumunun satın alma niyetine etkisinin kısmi olarak ünlü desteği ile sağlandığını göstermiştir. Bu sonuç da, sosyal medya reklamlarında ünlü desteğinin önemini vurgulamaktadır.

\section{2. Çalışmanın Kısıtları}

Bu çalışmanın, diğer tüm çalışmalarda olabileceği gibi bazı kısıtları bulunmaktadır. Çalışma Gaziantep ilinde yaşayan ve $Y$ Kuşağında bulunan tüketicileri kapsamaktadır. Bu noktada, Y Kuşağında yer almayıp aktif bir sosyal medya kullanıcısı olan diğer kuşaklara dâhil bireylerin de varlığı ve bu çalışmaya dâhil edilmemiş olması çalışma açısından bir kısıt olarak kabul edilebilir. Çalışmaya ait olarak kabul edilebilecek bir diğer kısıt da araştırmaya dâhil edilen katılımcıların sadece Gaziantep ilinden seçilmiş olmasıdır. Katılımcılara kısa sürede ulaşabilme noktasında Gaziantep ili seçilmiştir. Bu bağlamda daha farklı şehir, bölge ve katılımcıların da araştırmaya dâhil edilebilmesi ile önemli sonuçlar elde edilebilecektir. Anketi cevaplayanların tüm ifadeleri dikkatle okuyarak cevaplandırdığı varsayılmaktadır. Bu araştırmanın sonuçları farklı sektörlerde üretim yapan firma yöneticileri ve mal, hizmet ve marka tanıtım çalışmaları için aktif bir rol üstlenen reklam şirketleri için faydalı olacaktır. Çalışma sonuçları temel alınarak, firma yöneticilerine, tanınmış, alanında uzman, güvenilir ve çekici ünlü kişilerle iş birliğini içeren sosyal medya reklamlarına ağırlık vermeleri tavsiye edilebilir. Tüketiciler, zaman ve mekân fark etmeden sosyal medya reklamlarından, mal ve hizmetlerle ilgili fikir alabilmektedir. Bu açıdan, sosyal medyada aktif biçimde yer alan markalar tüketiciler tarafından kolaylıkla hatırlanabilecek ve marka farkındalığı sağlanması noktasında önemli bir adım atılmış olacaktır. 


\section{Kaynakça}

Akkaya, D.T. (2013). Sosyal medya reklamlarında tüketici algılarının tutum, davranış ve satın alma niyeti üzerine etkisi. Doktora Tezi, Trakya Üniversitesi Sosyal Bilimler Enstitüsü İşletme Anabilim Dalı, Edirne.

Aksoy, H. (2019). Türk tüketicilerin lüks ürün satın alma davranışları üzerinde dinin etkisinin analiz edilmesi. Gaziantep University Journal of Social Sciences, 18(2), 581-596.

Aksoy, H. ve Gür, A. (2018). Üniversite öğrencilerinin sosyal medya reklamlarına ilişkin algılarının satın alma niyeti üzerindeki etkisi: Gaziantep üniversitesi örneği. Cumhuriyet Üniversitesi İktisadi ve İdari Bilimler Dergisi, 19(1), 129-148.

Akyüz, A. (2010). Reklama yönelik tutum: belirleyici faktör olarak inançlar. Marmara İletişim Dergisi, 17(17), 214-227.

Altunışık, R., Coşkun, R., Bayraktaroğlu, S. ve Yıldırım, E. (2010). Sosyal Bilimlerde Araştırma Yöntemleri-SPSS Uygulamall. Sakarya, Sakarya Yayıncilik.

Azeem, A. and Haq, Z. (2012). Perception towards internet advertising: A study with reference to three different demographic groups. Global Business and Management Research: An International Journal, 4(1), 28-45.

Barnes, S., Bauer, H. H., Neumann, M. M. and Huber, F. (2007). Segmenting cyberspace: A customer typology for the internet. European Journal of Marketing, 41(1/2), 71-93.

Baron, R.M. and Kenny, D.A. (1986). The moderator-mediator variable distinction in social psychological research: Conceptual, strategic, and statistical considerations. Journal of Personality and Social Psychology, 51(6), 1173-1182.

Bentler, P.M. (1990). Comparative fit indexes in structural models. Psychological Bulletin, 107(2), 238-46.

Bergkvist, L., Hjalmarson, H. and Mägi, A.W. (2015), A new model of how celebrity endorsements work: Attitude toward the endorsement as a mediator of celebrity source and endorsement effects. International Journal of Advertising, 35(2), 171-184.

Bozkır, Ö., Taşpınar, C.D. ve Turanlı M. (2012). Faktör analizi ile üniversiteye giriş sınavlarındaki başarı durumuna göre illerin siralanması. İstanbul Üniversitesi İktisat Fakültesi Ekonomi ve İstatistik Dergisi, 17(1), 45- 68.

Çağlıyan, V., Işıklar, Z.E. ve Hassan, S. . (2016). Üniversite öğrencilerinin satın alma davranışlarında sosyal medya reklamlarının etkisi: Selçuk Üniversitesi'nde bir araştırma. Selçuk Üniversitesi Sosyal ve Teknik Araştırmalar Dergisi, 11, 43-56.

Çardaklı, S. (2008). Televizyon reklamlarında tanınmış kişilerin kullanılmasının reklamın hatırlanması üzerindeki etkisi konusunda bir pilot araştırma. Yüksek lisans tezi, Trakya Üniversitesi Sosyal Bilimler Enstitüsü İşletme Anabilim Dalı, Edirne.

Cheung, G.W. and Lau, R.S., (2008). Testing mediation and suppression effects of latent variables: Bootstrapping with structural equation models. Organizational Research Methods, 11(2), 296-325.

Çinkay, B. (2017). Sosyal medya pazarlamasında ünlü onaylayanların tüketici algısı ve satın alma niyeti üzerine etkisi. Doktora tezi, Kahramanmaraş Sütçü İmam Üniversitesi Sosyal Bilimler Enstitüsü İşletme Ana Bilim Dalı, Kahramanmaraş.

Ducoffe, R.H. (1996). Advertising value and advertising on the web. Journal of Advertising Research, 36(5), 2135.

Erdoğan, B.Z. (1999). Celebrity endorsement: A literature review. Journal of Marketing Management, 15(4), 291314.

Febrian, A. and Fadly, M. (2021). Brand trust as celebrity endorser marketing moderator's role. Jurnal Aplikasi Manajemen (Journal of Applied Management), 19(1), 207 -216,

Fishbein, M. (1967). A behavior theory approach to the relations between beliefs about an object and the attitude toward the object. Fishbein, M. (Ed.), Readings in Attitude Theory and Measurement. New York, John Wiley \& Sons, 389-400.

Fornell, C. and Larcker, D.F. (1981). Structural equation models with unobservable variables and measurement error: Algebra and statistics. Journal of Marketing Research, 18(3), 382-388. 


\section{H. Aksoy - A. Gür - E. Celep 13/3 (2021) 2340-2355}

Gökalan, B. (2009). Dayanıkh tüketim malları sektöründe ülke orijininin tüketicinin satın alma niyetine etkisi. Yüksek lisans tezi, Ankara Üniversitesi Sosyal Bilimler Enstitüsü İşletme Anabilim Dalı, Ankara.

Gupta, A., Chen, I.J. and Chiang, D. (1997). Determining organizational structure choices in advanced manufacturing technology management. Omega: The International Journal of Management Science, 25(5), 511-521.

Gülmez, M. ve Dörtyol, İ.T. (2013). Açıklamalı Pazarlama Sözlü̈̆̈̈̈. Ankara, Detay Yayıncılık.

Ha, N.M. and Lam, N.H. (2017). The effects of celebrity endorsement on customer's attitude toward brand and purchase intention. International Journal of Economics and Finance, 9(1), 64-77.

Haghirian, P., Madlberger, M. and Tanuskova, A. (2005). Increasing advertising value of mobile marketingan empirical study of antecedents. Proceedings of the 38th Hawaii International Conference on System Sciences, Hawaii, 1-10.

Hooper, D., Coughlan, J. and Mullen, M.R. (2008). Structural equation modelling: Guidelines for determining model fit. Electronic Journal of Business Research Methods, 6(1), 53-60.

Ilicic, J. and Webster, C.M. (2011). Effects of multiple endorsements and consumer-celebrity attachment on attitude and purchase intention. Australasian Marketing Journal, 19, 230-237.

İnce, M. ve Bozyiğit, S. (2018). Tüketicilerin Instagram reklamlarına karşı tutumlarının satın alma davranışları üzerindeki etkisi: Y ve Z kuşağı üzerine bir araştırma. Beykoz Akademi Dergisi, 6(2), 39-56.

Kirezli, D. (2015). Reklamlarda ünlü kişilerin kullanımının müşterilerin satın alma tercihleri üzerindeki etkisi: Thy örneği. Yüksek lisans tezi, Beykent Üniversitesi Sosyal Bilimler Enstitüsü İşletme Yönetimi Anabilim Dalı, İstanbul.

Kline, R.B. (2015). Principles and Practice of Structural Equation Modeling. New York, Guilford Publications.

Kuş, Ö.A. (2016). Bir pazarlama aracı olarak mobil pazarlama: İstanbul ili kapsamında y kuşağının mobil pazarlamaya bakış açısı. Yüksek lisans tezi, Okan Üniversitesi Sosyal Bilimler Enstitüsü İşletme Anabilim Dalı, İstanbul.

Kuyucu, M. (2017). Y kuşağı ve teknoloji: Y kuşağının iletişim teknolojilerini kullanım alışkanlıkları. Gümüşhane Üniversitesi İletişim Fakültesi Elektronik Dergisi, 5(2), 845-872.

Lutz, R.J., MacKenzie, S.B., and Belch, G.E. (1983). Attitude toward the ad as a mediator of advertising effectiveness: Determinants and consequences. Advances in Consumer Research, 10(1), 532-539.

Madahi, A. and Sukati, I. (2012). The effect of external factors on purchase intention amongst young generation in Malaysia. International Business Research, 5(8), 153-159.

McCracken, G. (1989). Who is the Celebrity Endorser? Cultural foundations of the endorsement process. Journal of Consumer Research, 16(3), 310-321.

Meral, P.S. (2006). Kurumsal reklam kavramı ve bankacilık sektöründeki kurumsal reklam örnekleri, 2. Ulusal Halkla İlişkiler Sempozyumu, Kocaeli Üniversitesi İletişim Fakültesi, Kocaeli, 393-403.

Mikalef, P., Giannakos, M. and Pateli, A. (2013). Shopping and word-of-mouth intentions on social media. Journal of Theoretical and Applied Electronic Commerce Research, 8(1), 17-34.

Nasir, N., Khan, S., Sabri, P. and Nasir, S. (2016). Celebrity endorsement and consumer buying intention with the mediating role of brand performance: An empirical consumer perception study in Fmcg sector of Pakistan. Sci. Int.(Lahore), 28(1), 617-624.

Nguyen, N. (2021). The influence of celebrity endorsement on young vietnamese consumers' purchasing intention. Journal of Asian Finance, Economics and Business, 8(1), 951-960.

Ohanian, R. (1990). Construction and validation of a scale to measure celebrity endorsers' perceived expertise, trustworthiness, and attractiveness. Journal of Advertising, 19(3), 39-52.

Ohanian, R. (1991). The impact of celebrity spokespersons' perceived image on consumers' intention to purchase. Journal of Advertising Research, 31(1), 46-54.

Pollay, R. W. and Mittal, B. (1993). Here's the beef: Factors, determinants, and segments in consumer criticism of advertising. Journal of Marketing, 57(3), 99-114.

Schumacker, R. E., and Lomax, R. G. (2004). A Beginner's Guide To Structural Equation Modeling. Psychology Press. 


\section{H. Aksoy - A. Gür - E. Celep 13/3 (2021) 2340-2355}

Sekaran, U. (1992). Research Methods For Business-A Skill Building Approach. (2nd Ed). United States of America, John Wiley \& Sons, Inc.

Smyrl, B. J. (2011). Leading a multi-generational workforce: Understanding generational differences for effective communication. Professional Project, Marquette University, Milwaukee, Wisconsin.

Solak, B.B. (2016). Televizyon reklamlarında ünlü kullanımının satın alma davranışı üzerine etkisi: Akdeniz üniversitesi iletişim fakültesi öğrencilerine yönelik araştırma. Gümüşhane Üniversitesi İletişim Fakültesi Elektronik Dergisi, 4(1), 253-278.

Spry, A., Pappu, R. and Bettina Cornwell, T. (2011), Celebrity endorsement, brand credibility and brand equity. European Journal of Marketing, 45(6), 882-909.

Steiger, J.H. (1990). Structural model evaluation and modification: An interval estimation approach. Multivariate Behavioral Research, 25(2), 173-180.

Sümer, N. (2000). Yapısal eşitlik modelleri: Temel kavramlar ve örnek uygulamalar. Türk Psikoloji Yazıları, 3(6), 49-73.

Tabachnick, B.G. and Fidell, L.S. (2001). Using Multivariate Statistics. 4th Edition. Boston, Allyn and Bacon.

Tsang, M.M., Ho, S. and Liang, T. (2004). Consumer attitudes toward mobile advertising: An empirical study. International Journal of Electronic Commerce, 8(3), 65-78.

Uçar, F. (2013). Tüketicilerin internet reklamlarına yönelik tutumları. Selçuk Üniversitesi İletişim Fakültesi Akademik Dergisi, 8(1), 128-143.

Ural, A. ve Kılıç, İ. (2005). Bilimsel Araştırma Süreci ve SPSS ile Veri Analizi. Ankara, Detay Yayıncılık.

Ünal, S., Erciş, A. and Keser, E. (2011). Attitudes towards mobile advertising - A research to determine the differences between the attitudes of youth and adults. Procedia Social and Behavioral Sciences, 24, 361-377.

Wang, J. S., Cheng, Y. and Chu, Y. (2013). Effect of celebrity endorsements on consumer purchase intentions: Advertising effect and advertising appeal as mediators. Human Factors and Ergonomics in Manufacturing and Service Industries, 23(5), 357-367.

Wang, S. W., Kao, G. H. and Ngamsiriudom, W. (2017). Consumers' attitude of endorser credibility, brand and intention with respect to celebrity endorsement of the airline sector. Journal of Air Transport Management, 60, 10-17.

Wang, Y. and Sun, S. (2010). Examining the role of beliefs and attitudes in online advertising a comparison between the USA and Romania. International Marketing Review, 27(1), 87-107.

Wang, Y., Sun, S., Lei, W. and Toncar, M. (2009). Examining beliefs and attitudes toward online advertising among Chinese consumers. Direct Marketing: An International Journal, 3(1), 52-66.

Weston, R., and Gore, P.A. (2006). A brief guide to structural equation modeling. The Counseling Psychologist, 34(5), 719-751.

Wolin, L.D., Korgaonkar, P. and Lund, D. (2002). Beliefs, attitudes and behaviour towards web advertising. International Journal of Advertising, 21(1), 87-113.

Yaşlığlu, M.M. (2017). Sosyal bilimlerde faktör analizi ve geçerlilik: keşfedici ve doğrulayıcı faktör analizlerinin kullanılması. Istanbul University Journal of the School of Business, 46(Özel Sayı), 74-85

Yücel, N. ve Kızkapan, L. (2016). Sosyal medyanın tüketici satın alma karar sürecine etkisi: Elazığ ili örneği. The Journal of Academic Social Science Studies, 53, 481-499.

Zengin, G. (2018). Banka reklamlarında mizah ve ünlü kullanımı: Reklam tutumlarına yönelik bir araştırma. Jass Studies-The Journal of Academic Social Science Studies, 65, 417-432.

https://wearesocial.com/global-digital-report-2019 (Erişim Tarihi:15 Mart 2021) 